\title{
Labor's Attitude Toward Methods of Management
}

\author{
By JohN P. Frey \\ Editor, International Molders' Journal
}

T HERE is one subject upon which little difference of opinion exists today. The world stands in urgent need of greater production. Statesmen, economists, manufacturers, financiers and trade-unionists are all agreed that the enormous waste caused by the war and the crushing burden of national indebtedness which followed can only be overcome by productionthe creation of sufficient wealth to liquidate the debts of the world, and to give greater comforts and opportunities to the mass of the people than they have enjoyed before.

\section{Management and Labor in Pro- DUCTION}

In its broadest aspect, production depends upon several factors, which include in their number, demand, credit, raw material, labor and transportation. For the present purpose the problem is being considered solely in the field of management and labor. Here we find that, while there is unanimity of opinion as to the necessity for better production, there is but little agreement upon the methods which must be adopted to develop the greatest degree of production with the greatest benefit to industry and the community.

It is not a particularly difficult task to state the formula for production. The problem lies in applying it in a practical manner. The basis for successful production is coöperation between management and labor and successful coöperation is based upon confidence between those who are to coöperate. But how is this confidence to be established?
Successful production requires that there shall be method, system and discipline. With this conception there will be no valid objection. The vital question which arises is the authority which is to select and determine upon the method or system, and apply or supervise the discipline.

If management is to assume the sole right to determine what system is to be applied to secure better production and what rules, regulations and discipline are necessary to make it effective, no profound knowledge of human nature is required to realize that labor, under such circumstances, cannot give its fullest coöperation.

Systems and rules for production can only work successfully where there is coöperation and the right mental attitude, and these cannot be created unless those, who are to participate jointly in production, jointly agree upon the conditions under which it will be carried on.

Is it possible to establish a condition where confidence will exist between management and labor unless these two important parties to production have become acquainted with each other, and with the problems which affect both and, in addition, have jointly worked out the rules and regulations under which coöperation is to be carried on?

Industry in America has not been carried on as economically and as effectively as it might have been, one prominent reason being the lack of confidence which has existed on the part of management toward labor and on the part of labor toward manage- 
ment. Management, at times, has apparently believed that satisfactory production depended wholly upon rules, methods and systems worked out and applied by management alone.

Labor has been made to feel, on more than one occasion, that its sole function was to obey orders, and frequently to obey them blindly, and, where this condition has existed, it has unquestionably created an attitude on the workers' part where they had but little interest in production and none of the spirit of coöperation which is so essential.

For a number of years previous to the war able men, animated by most worthy motives, endeavored to devise methods and systems which, if applied to industry, would establish greater production. But these systems, regardless of their individual merits, largely failed to solve the problem. Under their operation labor, as a whole, became more dissatisfied and less willing to coöperate. Production was something which was forced, instead of something which came as a result of good will and a spirit of confidence and coöperation.

The American trade-union movement believes in progress. It is the only hope for the future. It recognizes that progress means change and readjustment, and it has no objection to changes, but American labor may have serious objections to the method by which changes are made.

Labor has objected in the past and will object in the future, whenever it believes that it is being experimented upon and experimented with by others, without having a voice as to the necessity, the value, or the character of the experiments taking place during a period of change. Labor feels fully justified in this position, for, from the mass of industrial experiments in which the human factor plays a promi- nent part, we find that the majority have resulted in failure. It must be recognized that there is a distinct difference between experiments with material and experiments with human beings.

If labor has realized that production was necessary to the creation of wealth, and wealth was necessary if higher wages and other improved terms of employment were to be secured, why is it that labor frequently indicated a frank unwillingness to coöperate with management when new methods or systems of production were applied?

\section{Labor's Atrtiude Toward Produc- TION Systems}

One prominent reason for labor's position is not difficult to discover. Labor was suspicious of these systems; suspicious because it had not been consulted, and had had no part in preparing them; suspicious because they were, unfortunately, frequently advertised as methods by which skilled labor could be supplanted by unskilled labor; suspicious because it was claimed that scientific methods had been worked out which enabled management, and management solely, to determine what degree of exertion, what amount of production labor should produce within a given time; suspicious because in practice these systems were largely applied by men having little, if any, practical personal experience as manual or skilled workmen; suspicious because the mathematician and the mechanical engineer were held to be the only ones competent to determine the methods, processes and the amount of energy which the workman should put into the day's work.

Facts are facts, and no good can come from sidestepping them, or glossing them over.

Labor, before the war, rose in 
opposition to the several systems of production which had been loosely called "scientific management." As labor was directly affected, it was interested in time studies, in the subdivision of labor and the basis of computation for the payment of wages. For a number of years there existed an active controversy between those who advocated so-called scientific management and the trade-unionists. As a result of an investigation made under the authority of the Industrial Relations Commission, it was made evident that the term "scientific management," applied to these systems, was an unfortunate one because none of them had reached that stage where the term "scientific" was appropriate.

The internal evidence, contained in the investigating commission's report, satisfactorily disposed of the contention that time studies of labor could be made with scientific accuracy; they disclosed that the human element was a factor which could not be reduced to scientific accuracy by the use of the stop-watch, or any other methods, for men differ in their mentality, their vitality, their nervous reaction, the time required to recover from fatigue as well as in a number of other qualities.

Sometime after the report on scientific management and labor, above referred to, had been published, one of the production engineers in the scientific management group, in a communication to the writer, said in substance: "I will admit that you have proved the unscientific character of much that has been termed 'scientific management' and that no one can suceessfully claim today that time studies of labor can be made which are scientifically acurate. You have killed these claims and you may kill others, but the soul of efficiency cannot be killed. Certain fundamental truths which were worked out by efficiency engineers will live regardless of how incumbered they may have been by false claims, and by the pretentions of those who saw in the new conceptions of production an opportunity of exploitation for personal ends."

An unprejudiced examination of what has been done by the efficiency or production engineers bears out the basic truth contained in the statement that the soul of efficiency cannot be killed. Unquestionably, there was much in scientific management which was sound, for, if labor could be charged with inefficiency at times, in many instances management in American industries could be charged with a much greater volume, as well as the burden of responsibility. In fact, those who have studied the methods or lack of methods of management which existed a number of years ago are frequently surprised that it was possible to have kept the sheriff from the door, under the cumbersome, inadequate and unintelligent system of production which existed in many plants.

In company with Professor Robert F. Hoxie and Mr. Robert G. Valentine, the other members of the commission, the writer investigated a large eastern manufacturing plant. A "scientific management" engineer had installed his system in the plant after some two years' work and a cost to the firm of approximately $\$ 40,000$. The installer of the system had been more competent as a mathematician and a mechanical engineer than as a psychologist or economist; he had apparently known little about human nature. Owing to the fatal defects which had developed in the system which he had installed, it had been eliminated from the plant, root and branch. However, the president of the corporation stated that it was the most profitable $\$ 40,000$ he had ever spent, because it had given him an opportunity of studying production 
in his plant from a viewpoint which he had never grasped before, and had enabled him to install methods of production far more satisfactory and successful than those he had originally worked out.

\section{Difficulties of Production Systems}

For a period before the war, there was little in the direction of production in many plants which brought the higher management into direct contact with labor. Wasteful methods, with which the workmen were familiar, were not called to the management's attention because the management believed that it was fully equipped and allsufficient to direct production, and there was, to quite an extent, the same measure of coöperation between management and labor which existed between the Czar of Russia and many of his subjects-there was compulsory regulation in the place of a spirit of loyalty and coöperation.

When systems for the regulation and stimulation of production were first applied, too much confidence apparently was placed in the system and not enough consideration given to the human factors which were involved, and the systems were frequently accompanied by the promise, the understanding, or the belief that their introduction and application would prevent labor troubles and establish a condition under which trade-unionism could not function successfully.

If a system applied in one plant could be shown by charts and statistics to have accomplished remarkable results in increasing production and reducing labor costs, this in itself was no proof that when applied in other plants it would produce similar results. Methods of soil cultivation on the rich plains of the central west would not work efficiently on the rocky, uneven but fertile soil of the New England states. Methods of directing coolie labor in Asia, no matter how successful there, in all likelihood could not be satisfactorily applied in America to Amercan workmen.

Among those who, a few years ago, were endeavoring to work out the problem, were engineers who saw the problem almost wholly from the position which they occupied, and who had failed to sufficiently examine or understand it from the view point of those occupying different positions. Some, with the stark enthusiasm of theorists, devised methods and systems which they applied with as much fervor as crusaders, but with as little sound judgment as the hydropaths who, finding that certain applications of humidity or water to the human body produced beneficial results in certain cases, conceived the idea that all of the ills to which the human flesh is heir could be speedily cured by wet packs.

The facts are more valuable than illustrations or theories. The outstanding fact is that the various systems of production, so widely advertised and discussed a few years ago, failed to bring about that quality and quantity of production which should be the ideal of both management and labor. They failed to establish mutual confidence and, because of this, failed to create a condition of healthful cooperation between management and labor.

While some efficiency engineers were claiming that highly skilled labor was no longer required, because, through systems of production and subdivision of the work, it was no longer necessary to employ the old-fashioned craftsman, other men believed that one of the handicaps to successful production was the lack of craft and manual knowledge on the part of many workers. Commendable efforts were, and are still being made through trade 
schools, vestibule schools and other methods to build up the craft, manual and technical knowledge of the workers so that there might be a general improvement in mechanical knowledge on the workmen's part.

Unfortunately, some of the early trade schools were subsidized by employers' associations who had more than one motive in mind in maintaining these institutions, and others were controlled by men whose motives and ambitions outran their practical knowledge of what was essential. And here again there was but slight coöperation between the mass of the workers who were to be benefited and those who were to confer the benefits, the latter feeling themselves amply qualified to direct and advise, but little inclined to accept suggestions or work jointly with the workers and their representatives.

\section{Upon What Does Satsifactory Production Depend?}

Improved production depends upon a continual increasing development of mechanical knowledge and skill on the workman's part; it depends upon system, for, unless there is system, there cannot be efficiency. But it depends more than anything else upon coöperation which in turn depends upon mutual confidence. The great problem of production is, first of all, the establishing of mutual confidence.

How is this to be established?

It cannot be established if one of the parties to production considers himself superior to the other, or relies upon its strength of numbers or of position. It cannot be established if one of the parties lays down the rules which are to govern the other. No man or group of men are so wise and gifted with so much natural ability that they are competent to prepare and enforce the rules which are to govern others. At the very best, they can but adopt the rules under which they themselves are to be governed.

Management, consulting with itself, is not competent to work out the most successful methods of production; labor consulting with itself is no more competent, for production is a joint product, it is the result of coöperation between a number of men occupying different positions and responsibilities. The most competent managers, operating with a most competent staff of subordinates, are no more competent to work out the complicated human problem which plays so important a part in production than the trade unions would be to work out this problem without conferences with management and an examination of the factors which must be understood and which must be recognized if production is to be successful.

The trade-union movement has no patented systemfor solving the problem of production. It places abiding faith in no system, because man-made systems must of necessity have their defects and shortcomings, and systems devised wholly by management may have and frequently do have ulterior purposes which do not show themselves upon the surface. But the American trade-union movement has unlimited confidence in methods and principles, and it is through the application of these that it sees the most effective solution of the problem. The American trade-union movement is fully aware of the fact that wages depend upon production and that wages are drawn not from the wealth which may have been accumulated in the past, but from the production of today and tomorrow.

Labor is fully aware of the fact that the comforts of life and the opportunities for better things in the future depend upon a satisfactory volume of production. It bases its hope upon the 
building up instead of the tearing down of industry. But labor is quite convinced, as a result of its experiences, that satisfactory production cannot exist unless there is coöperation, and the principles and the methods which it believes to be essential to establish this are those which underlie the institutions of our common country - the principles and the methods of democracy.

The citizens of the United States are loyal and they coöperate to as great, if not a greater degree than the citizens of any other country, and this is because there is a form of government in the United States under which government exists only with the consent of the governed. These principles and the methods are as sound in industry as they are in civil affairs.
In these days, with the conceptions and ideals which have so firmly fixed themselves in men's minds, the principle of autocracy or arbitrary power no longer enjoys the approval of the majority. The problem of satisfactory production hinges largely upon whether industry is to be group-governed or self-governed, and if it is to be selfgoverned, it is essential that management and labor should consult together and jointly work out the rules and the conditions under which labor is to perform its part and management is to function.

Control of industry by management, without coöperation and consultation with labor, is as impractical today as would be the effort of group government for the people without their consent. 